ORIGINAL

\title{
Serological evidence of Hepatitis E Virus infection in Antioquia, Colombia slaughtered pigs
}

\section{Evidencia serológica de infección por el Virus de Hepatitis E en cerdos faenados en Antioquia, Colombia}

\author{
Jorge Forero D, ${ }^{1 *}$ M.Sc, Cristian Gutiérrez $\mathrm{V}_{1}{ }^{1}$ M.Sc, Jaime Parra $\mathrm{S}_{,}{ }^{1} \mathrm{Ph} . \mathrm{D}$, \\ Guillermo Correa L, ${ }^{1}$ Ph.D, Berardo Rodríguez, ${ }^{2}$ Ph.D, Lina Gutiérrez B, ${ }^{3}$ Ph.D, \\ Albeiro López-Herrera. ${ }^{1}$ Ph.D.
}

\begin{abstract}
${ }^{1}$ Universidad Nacional de Colombia, Facultad de Ciencias Agrarias. Departamento de Producción Animal, Grupo Biodiversidad y Genética Molecular BIOGEM. Calle 59A No.63-020, Autopista Norte, Bloque 50, Piso 3, Oficina 310. Medellín, Colombia. ${ }^{2}$ Universidad de Antioquia. Facultad de Ciencias Agrarias. Laboratorio de Patología Animal. Grupo de Investigación en Patobiología QUIRON. Carrera 75 No. 65-87. Bloque 47-134. Medellín. Colombia.. '3niversidad Pontificia Bolivariana, Facultad de Medicina, Escuela de Ciencias de la Salud, Grupo Biología de Sistemas, Calle 78B N²72A-109, Bloque B. Medellín, Colombia. *Correspondencia: jforeroduarte@gmail.com
\end{abstract}

Received: June 2014; Accepted: December 2014.

\begin{abstract}
Objective. To detect the presence of specific antibodies against Hepatitis E virus (HEV) in pigs slaughtered in Antioquia, the department where the greatest amount of pork is produced and consumed in Colombia. Materials and methods. Between September 2011 and May 2012, blood samples from pigs were obtained in five slaughterhouses of Antioquia, four of them located in the Aburrá Valley subregion and other located in northern subregión. Serum were evaluated with a commercial ELISA kit for diagnosing HEV in humans but adapted to detect IgG and IgM antibodies in pigs. Results. A $100.0 \%$ seropositivity for IgG antibodies was found in 1000 samples evaluated, and $82.06 \%$ for IgM antibodies were found in 740 samples. Conclusions. These results indicate that pigs in slaughter age in Antioquia, and possibly in Colombia, have been exposed to HEV at some point in their production process and a high percentage of them can arrive to slaughterhouses with recent infection.
\end{abstract}

Key Words: Antibodies, ELISA, Hepevirus, IgM, IgG, zoonosis (Source: DeCS).

\section{RESUMEN}

Objetivo. Detectar la presencia de anticuerpos específicos contra el virus de la Hepatitis E (HEV) en cerdos faenados en Antioquia, departamento donde se produce y consume la mayor cantidad de carne de cerdo en Colombia. Materiales y métodos. Entre septiembre de 2011 y mayo de 2012, se obtuvieron muestras de sangre de cerdos en cinco plantas de faenado, cuatro de ellas ubicadas en el Valle de Aburrá y una en la subregión Norte del departamento de Antioquia, las cuales fueron evaluadas mediante un kit de ELISA comercial para diagnóstico de HEV en humanos pero adaptado para la detección de anticuerpos tipo IgG e IgM en cerdos. Resultados. Se encontró una seropositividad de $100.0 \%$ para anticuerpos tipo IgG en 1000 muestras evaluadas y de $82.06 \%$ para anticuerpos tipo 
IgM en 740 muestras. Una muestra de heces positiva para la detección del genoma HEV es similar al genotipo 3 encontrada en Estados Unidos. Conclusiones. Estos resultados indican que los cerdos en edad de faenado en Antioquia y posiblemente en Colombia, han tenido exposición a HEV del, un virus zoonótico emergente a nivel mundial, en algún momento de su proceso productivo.

Palabras clave: Anticuerpos, ELISA, Hepevirus, IgM, IgG, zoonosis (Fuente: DeCS).

\section{INTRODUCTION}

Hepatitis $E$ is an acute liver disease in humans caused by the hepatitis E virus (HEV). Although this type of hepatitis has a global distribution, in some countries of Africa and Asia outbreaks associated with contamination of water sources for consumption are presented, while in other regions such as Europe and the United States there are sporadic outbreaks associated with the consumption of raw or undercooked food $(1,2)$. It is estimated that every year around the world, 20 million humans are infected, with about three million cases of acute hepatitis and 57,000 deaths related to Hepatitis E (1.3). Most of the time the disease is self-limiting in humans; however, it can be extremely serious for pregnant women, and the mortality rate for this population may exceed $20 \%$ (4).

There are four major HEV genotypes that are recognized in mammals. Genotypes 1 and 2 are restricted to humans while genotypes 3 and 4 can infect, in addition to humans, other species, mainly domestic pigs (3). Genotype 1 is found mainly in India, while genotype 2 has been detected in several countries of Africa and in Mexico. Genotype 3 is found around the world, while genotype 4 is often found in Asian countries like China and Japan (1-3).

In Latin America, the first serologic evidence of the virus in humans was found in Venezuela in 1994; later, in other research on the seroprevalence of HEV in countries in the region, varying percentages were found in the different human populations studied, none of which exceed $20 \%$ (5). Additionally, the viral genome has been detected in humans in Argentina, Brazil, Bolivia and Uruguay, where genotype 3 has been identified; however, in Venezuela and Argentina genotype 1 has been found (5).

In addition to the findings in humans, serologic evidence of infection has been found in other species such as cattle, dogs and chickens (6), and the viral genome in wild boars, deer, rabbits, rats and bats $(2,7,8)$ but it is still unclear what role these species play in the epidemiology of the infection. On the other hand, the increased

\section{INTRODUCCIÓN}

La Hepatitis E es una enfermedad hepática aguda en humanos causada por el Virus de la Hepatitis E (HEV). Aunque este tipo de hepatitis presenta una distribución global, en algunos países de Africa y Asia se presentan brotes epidémicos asociados a contaminación de fuentes de aguas para consumo humano, mientras que en otras regiones como Europa y Estados Unidos se presentan brotes esporádicos asociados al consumo de alimentos crudos o mal cocidos $(1,2)$. Se estima que en el mundo cada año hay 20 millones de infecciones en humanos, cerca de tres millones de casos de hepatitis aguda y 57.000 muertes relacionadas a la Hepatitis E $(1,3)$. La mayoría de las veces la enfermedad es auto limitada en el humano; sin embargo, puede llegar a ser extremadamente grave en mujeres embarazadas, con una mortalidad para esta población que puede superar el $20 \%$ (4).

Se reconocen cuatro genotipos de HEV en mamíferos. Los genotipos 1 y 2 están restringidos a los humanos, mientras que los genotipos 3 y 4 pueden infectar además, de humanos otras especies, como el cerdo (3). El genotipo 1 se ha encontrado principalmente en India, mientras que el genotipo 2 se ha detectado en varios países de África y también en México. El genotipo 3 presenta una distribución mundial, mientras que el genotipo 4 se encuentra frecuentemente en países asiáticos como China y Japón (1-3).

En Latinoamérica, la primera evidencia serológica del virus en humanos se encontró en Venezuela en 1994; posteriormente en otras investigaciones sobre seroprevalencia de HEV en países de la región, se encontraron porcentajes variables en las distintas poblaciones humanas estudiadas, los cuales no superan el $20 \%$ (5). Junto a esto, el genoma viral se ha detectado en humanos en Argentina, Brasil, Bolivia y Uruguay, donde se ha podido identificar el genotipo 3; no obstante, en Venezuela y Argentina se ha encontrado el genotipo 1 (5).

Junto a los hallazgos en seres humanos, se ha encontrado evidencia serológica de la infección en otras especies como bovinos, perros y gallinas (6), 
risk of infection in swine handlers (9), the high genetic identity between swine and human HEV viral sequences $(10,11)$, and the experimental infection with swine genotypes to nonhuman primates, are findings which identified the pig as the viral reservoir of infection $(2,10,11)$.

Serological studies in swine show a wide distribution of the virus in herds around the world. In the United States seropositivity reached $41 \%$ (12), $90 \%$ in New Zealand (13), $100 \%$ in Mexico (14) and $98 \%$ in Spain (15). Studies in Latin America have reported the circulation of HEV in pigs in Argentina (16), Brazil (17), Chile (18), Costa Rica (19) and Mexico (14).

Pig production is an important part of the livestock sector in Colombia, with a positive impact on the economy, not only by promoting the livestock sector, but as a source of employment in the country (20). Antioquia is the department in Colombia with the greatest production and consumption of pork, as it provides about $45 \%$ of total production in the country (20).

Hepatitis E is considered a global public health problem; however, in Colombia, despite some isolated efforts, the status for HEV in the population is unknown, as well as the presence of specific antibodies in pigs bred in the country. The aim of this study was to determine the presence of IgG and IgM antibodies in pigs slaughtered in the main slaughterhouses in the department of Antioquia.

\section{MATERIALS AND METHODS}

Ethical aspects. This study was conducted in accordance with protocols approved by the Ethics Committee of the Universidad Nacional of Colombia, Medellin (Act CEMED-226, of October 14, 2011).

Sampling and size of sample. Sampling was conducted with slaughtered pigs between September 2011 and May 2012 at five slaughterhouses, four of them located in the Aburrá Valley and in the northern subregion of the department of Antioquia, which were identified in the present study with letters $A$ to $E$ (randomized) in order to maintain confidentiality. The selected plants process the majority of the swine production in Antioquia. The average number of animals slaughtered per day during the six months prior to the start of the study was $450,200,400,800$ and 400 animals in plants $A$, $B, C, D$ and $E$, respectively.

Based on the sample size required to estimate seropositivity in Antioquia with a confidence y del genoma viral en jabalíes, venados, conejos, ratas y murciélagos $(2,7,8)$, pero todavía no es claro el papel que desempeñan estas especies en la epidemiologia de la infección. Por otro lado, el mayor riesgo de infección que tienen las personas que manipulan cerdos (9), la alta identidad genética entre los genotipos detectados en cerdos y humanos $(10,11)$ y la infección experimental con los genotipos de cerdos en primates no humanos son hallazgos que permitieron identificar al cerdo como el reservorio para la trasmisión zoonótica del virus $(2,10,11)$.

Los estudios serológicos en cerdos, muestran una amplia distribución del virus en las piaras del mundo. En Estados Unidos la seropositividad alcanza el $41 \%$ (12), $90 \%$ en Nueva Zelanda (13), $100 \%$ en México (14) y $98 \%$ en España (15). Los estudios realizados en Latinoamérica han reportado la circulación de HEV en cerdos de Argentina (16), Brasil (17), Chile (18), Costa Rica (19) y México (14).

La producción porcina es parte importante del sector pecuario de Colombia, con un impacto positivo sobre la economía, no solo por favorecer al sector pecuario, sino por constituirse en una fuente de empleo en el país (20). Antioquia es el departamento colombiano con mayor producción y consumo de carne de cerdo, pues aporta aproximadamente el $45 \%$ de la producción total del país (20).

La Hepatitis E es considerada como un problema de salud pública mundial; sin embargo, en Colombia, a pesar de algunos esfuerzos aislados, se desconoce el estatus serológico para HEV en la población, al igual que la presencia de anticuerpos específicos en los cerdos que se crían en el país. El objetivo del presente trabajo fue determinar la presencia de anticuerpos IgG e IgM en cerdos beneficiados en las principales plantas de faenado del departamento de Antioquia.

\section{MATERIALES Y MÉTODOS}

Aspectos éticos. Este estudio fue realizado de acuerdo con los protocolos aprobados por el Comité de Ética de la Universidad Nacional de Colombia, sede Medellín (Acta CEMED-226, del 14 de octubre de 2011).

Muestreo y tamaño de muestra. El muestreo se realizó en una población de cerdos beneficiados entre septiembre de 2011 y mayo de 2012, en cinco plantas de faenado, cuatro de ellas ubicadas en el Valle de Aburrá y una en la subregión Norte del departamento de Antioquia, las cuales se identificaron en el presente estudio 
level of $95 \%$ and a maximum error of $3 \%$, a total of 1,000 samples were evaluated, allocating per plant the average daily amount of animals processed over the past six months. Within each slaughterhouse a sampling by quotas was performed, where each quota was calculated in proportion to the number of animals slaughtered in the subregion of origin. In each slaughterhouse, the pigs were selected systematically, with a random start.

Collecting information. The sampled animals were identified by place of origin, classified as healthy, and approved for slaughter and commercialization, according to the pre and postmortem health inspection done by the responsible veterinarians at each processing plant.

Serum samples. Blood samples were obtained on the slaughtering line after desensitizing the animal, at the time of bleeding. Approximately $10 \mathrm{ml}$ of blood was taken per animal in sterile 15 $\mathrm{ml}$ tubes. The samples were put in cold storage to be transported to the laboratory of Animal Biotechnology of the Universidad Nacional of Colombia, in Medellin, where they were immediately centrifuged at $1500 \mathrm{rpm}$ for 10 minutes to obtain the serum, which was stored at $-20^{\circ} \mathrm{C}$ until analyzed.

Indirect ELISA immunoenzymatic analysis to detect specific IgG and IgM antibodies against HEV. To detect IgG antibodies against HEV in pigs, the commercial kit of indirect ELISA HEV-IGAB (Dia.Pro-Diagnostic Bioprobes, Italy) for dual detection of IgG and IgM antibodies in human serum was used, replacing the antihuman conjugate with a conjugated goat antibody anti-IgG for swine (Thermo Fisher Scientific Inc, USA) according to the methodology used by other researchers $(17,21-23)$ at the dilution recommended by the manufacturer (1:5000). As a negative swine control (NPC), a serum of newborn piglets (in triplicate) that did not ingest colostrum was used, to avoid the presence of maternal antibodies; and as a positive control (CPP) a sample of the study that showed high OD values in the ELISA was employed. In each of the dishes that swine serum was evaluated, and for purposes of internal quality control for each test, the controls recommended and provided by the manufacturer were included: three negative controls (NC), a positive control (CP) and two calibrators (C) evaluated with the anti-human conjugate in the case.

To detect IgM antibodies to HEV in pigs, the same strategy previously mentioned was used, but a commercial indirect ELISA kit HEV-IgM (Dia.Pro-Diagnostic Bioprobes, Italy) was used, con letras de la A a la E (asignadas al azar) con el fin de guardar confidencialidad. Las plantas seleccionadas reciben la mayor parte de la producción de cerdos de Antioquia. El número promedio de animales sacrificados por día durante los seis meses previos al inicio del estudio fue de 450, 200, 400, 800 y 400 animales para las plantas $A, B, C, D$ y $E$, respectivamente. Tomando como base el tamaño muestral requerido para estimar la seropositividad en Antioquia, con un nivel de confianza del $95 \%$ y un error máximo de 3\%, se evaluaron en total 1000 muestras, con afijación por planta proporcional al promedio diario de beneficio de los últimos seis meses. Dentro de cada planta, se empleó un muestreo por cuotas, donde cada cuota se calculó proporcionalmente al número de animales beneficiados por subregión de procedencia. En cada planta, los cerdos fueron seleccionados de manera sistemática con inicio aleatorio.

Recolección de la información. Los animales muestreados fueron identificados por lugar de procedencia, clasificados como sanos, y aprobados para beneficio y posterior comercialización, según el proceso de inspección sanitaria pre y postmórtem realizado por los médicos veterinarios responsables de cada planta de beneficio.

Muestras de suero. Las muestras de sangre fueron obtenidas en la línea de faenado posteriormente a la insensibilización del animal, en el momento de la exanguinación. Se tomaron aproximadamente $10 \mathrm{ml}$ de sangre por animal en tubos estériles de $15 \mathrm{ml}$. Las muestras se almacenaron en frío para su transporte al laboratorio de Biotecnología Animal de la Universidad Nacional de Colombia, sede Medellín, donde fueron centrifugadas inmediatamente a 1500 r.p.m. durante 10 minutos, para la obtención del suero, el cual fue almacenado a $-20^{\circ} \mathrm{C}$ hasta su análisis.
Análisis inmunoenzimático ELISA indirecto para detección de anticuerpos IgG e IgM específicos contra HEV. Para la detección de anticuerpos tipo IgG contra HEV en cerdos, se empleó el kit comercial de ELISA indirecto HEV-IgAB (Dia.Pro-Diagnostic Bioprobes, Italia) para detección dual de anticuerpos tipo IgG e IgM en suero humano, para lo cual se remplazó el conjugado anti-humano del estuche, por un anticuerpo conjugado de cabra anti-IgG de cerdo (Thermo Fisher Scientific Inc, USA) acorde a la metodología usada por otros investigadores (17,21-23) a la dilución recomendada por el fabricante (1:5000). Como control negativo porcino (CNP) se utilizó (por triplicado) un suero de lechón recién nacido que no ingirió 
replacing the human anti-IgM conjugate with a goat antibody conjugate anti-IgM for swine (ScientificInc Thermo Fisher, USA) in a 1:5000 dilution recommended by the manufacturer. $A$ serum sample from a newborn piglet was used as CNP with the above mentioned characteristics, and as CPP a serum sample of a pig with molecular detection of viral shedding in feces affected by PCR for the ORF1 region of HEV. For purposes of internal quality control of each test, controls that are recommended and provided by the manufacturer were included: three $\mathrm{CN}$ and one $\mathrm{CP}$ evaluated with the anti-human conjugate of the case.

The microplate of the cases used in this study were coated with specific synthetic HEV antigens derived from the ORF2 and ORF3 regions of the 4 genotypes as described by the manufacturer. OD readings were obtained on an ELISA reader (Biotek, USA) with a $450 \mathrm{~nm}$ filter.

\section{Viability of the indirect modified ELISA test to detect IgG and IgM antibodies. To ensure the viability of the modified conjugated immunoassays with the anti-swine conjugates, initially a positive swine serum sample for IgG anti-HEV characterized and evaluated in a previous study, kindly donated by Dr. Munné (National Reference Laboratory for viral hepatitis INEI ANLIS "Carlos Malbrán", Argentina), (17). This serum was positive with the selected cutoff point in this project, but preliminary tests indicated that the optical density reading at $450 \mathrm{~nm}$ (OD 450) for the Argentine positive serum were two times lower than $\mathrm{DO}_{450}$ of some Colombian samples (data not shown); for this reason, and because the volume of the donated positive serum was insufficient to use as a positive control in all assays, the CPP and CNP described above were used.}

To assess the repeatability of ELISA assays modified anti- IgG and IgM in swine, six successive tests on different days, with two different operators and under the same laboratory conditions, were performed and a coefficient of variation (CV) was obtained with less than $20 \%$ gross absorbance values, so it was considered that the trials had adequate levels of repeatability $(23,24)$.

Estimating the value of the cut for positive IgG and IgM antibodies. Obtaining the cutoff for positivity of the IgG and IgM antibodies was performed based on Chebyshev inequality (25), which states that, regardless of the probability distribution of a random variable, no more than $\left(1 / k^{2}\right) \%$ of those distribution values found over $\mathrm{k}$ standard deviations from the mean. To control the probability of false positives, the maximum tolerable probability was set at 0.0102 , which calostro para evitar la presencia de anticuerpos maternales; y como control positivo porcino (CPP) se empleó una muestra del estudio que mostró altos valores de DO en la ELISA. En cada uno de los platos en los que se evaluaron sueros porcinos y para efectos de control de calidad interno de cada ensayo, se incluyeron los controles recomendados y proporcionados por el fabricante: tres controles negativos (CN), un control positivo (CP) y dos calibradores (C) evaluados con el conjugado anti-humano del estuche.

Para la detección de anticuerpos tipo IgM contra HEV en cerdos, se empleó la misma estrategia anterior, pero usando un estuche comercial de ELISA indirecto HEV-IgM (Dia.Pro-Diagnostic Bioprobes, Italia) remplazando el conjugado anti-IgM humano por un anticuerpo conjugado de cabra anti-IgM de cerdo (Thermo Fisher ScientificInc, USA) en una dilución 1:5000 recomendada por el fabricante. Se utilizó como CNP una muestra de suero lechón recién nacido con las características antes mencionadas, y como CPP una muestra de suero de un cerdo con detección molecular de excreción viral en heces efectuada mediante PCR para la región ORF1 de HEV. Para efectos de control de calidad interno de cada ensayo, se incluyeron los controles recomendados y proporcionados por el fabricante: tres CN y un CP evaluados con el conjugado anti-humano del estuche.

Las microplacas de los estuches utilizados en el presente estudio, estaban recubiertas con antígenos sintéticos específicos de HEV derivados de las regiones ORF2 y ORF3 de los 4 genotipos según lo descrito por el fabricante. Las lecturas de DO fueron obtenidas en un lector de ELISA (Biotek, USA) con un filtro a $450 \mathrm{~nm}$.

\footnotetext{
Viabilidad de la prueba de ELISA indirecta modificada para la detección de anticuerpos tipo IgG e IgM. Para asegurar la viabilidad de los inmunoensayos modificados con los conjugados anti-cerdo, se evaluó inicialmente una muestra de suero de cerdo positivo para IgG anti-HEV caracterizada y evaluada en un estudio previo, gentilmente donada por la Dra. Munné (Laboratorio Nacional de Referencia para las hepatitis virales INEI ANLIS "Carlos Malbrán" de Argentina), (17). Este suero fue positivo con el punto de corte seleccionado en este proyecto, pero los ensayos preliminares indicaron que la lectura de densidad óptica a $450 \mathrm{~nm}\left(\mathrm{DO}_{450}\right)$ para el suero positivo argentino fueron dos veces menores que las $\mathrm{DO}_{450}$ de algunas muestras colombianas (datos no mostrados), por esta razón, y debido a que el volumen del suero positivo donado era insuficiente para ser usado
} 
corresponds to the cutoff given by the average value of the readings of the negative controls plus seven standard deviations. Using this criterion, the cutoffs were 0.220 and 0.545 for IgG and IgM, respectively.

Statistical methods. Repeatability analysis was based on the evaluation of the DO results obtained by the CV, standard deviation (SD) and standard error (SE). Control charts of Levey Jennings were constructed from DO data using the Excel program. To analyze HEV seropositivity in pigs in the slaughterhouses and by geographic subregion, the frequencies of data were estimated, the confidence intervals (with a confidence level of 95\%) and differences between proportions (based on Fisher's exact test), with a confidence level of $95 \%$; they are considered significant at $p<0.05$. All analysis was performed using GraphPad Prism tools 5 (GraphPad Software, Inc. La Jolla, USA).

\section{RESULTS}

Repeatability and consistency of modified indirect ELISA tests to detect IgG and IgM antibodies. After determining the optimal dilution of the conjugate and the test samples, the repeatability of the test was evaluated by evaluating the CPP in six independent trials with two different operators. The CV values obtained for the CPP were $3.86 \%$ and $18.88 \%$ for IgG and IgM respectively (Table 1 ).

The $\mathrm{DO}_{450}$ values of the CPP in each of the tests for the two antibodies were controlled throughout the study by means of Levey-Jennings graphics as shown in figure 1 , the values obtained in each one of the determinations did not exceed the average value in more than two DE both for IgG as well as IgM. Similarly, it is noted that all the kit controls operated within the parameters defined

Table1. Repeatability of indirect ELISA assays with conjugated swine anti-IgG and anti-IgM.

\begin{tabular}{|c|c|c|}
\hline & $\begin{array}{c}\mathrm{DO}_{450} \text { Conjugated swine } \\
\text { anti-IgG } *\end{array}$ & $\begin{array}{c}\mathrm{DO}_{450} \text { Conjugated swine } \\
\text { anti-IgM } *\end{array}$ \\
\hline No & CPP & CPP \\
\hline $1^{\mathrm{a}}$ & 3.351 & 1.378 \\
\hline $2^{\mathrm{b}}$ & 3.196 & 0.832 \\
\hline $3^{a}$ & 3.466 & 0.918 \\
\hline $4^{b}$ & 3.170 & 1.050 \\
\hline $5^{b}$ & 3.444 & 1.165 \\
\hline $6^{b}$ & 3.421 & 1.265 \\
\hline$x$ & 3.346 & 1.101 \\
\hline DE & 0.118 & 0.2079 \\
\hline $\mathrm{EE}$ & 0.045 & 0.08489 \\
\hline $\mathrm{CV}$ & $3.86 \%$ & $18.88 \%$ \\
\hline
\end{tabular}

*Dilution1:5000; a Values obtained by one of the operators, b tests thtat were done by the second operator. Each one of the 6 tests was done under the same conditions but on different days. CPP: Positive Pig Control; X: Average; DE: Standard Deviation; EE: Standard Error; CV Coefficient of variation. como control positivo en todos los ensayos, se utilizaron los CPP y CNP descritos anteriormente.

Para evaluar la repetibilidad de los ensayos de ELISA modificada anti-IgG e IgM de cerdo, se realizaron seis ensayos consecutivos en días diferentes, con dos operarios distintos y bajo las mismas condiciones de laboratorio, y se obtuvo un coeficiente de variación (CV) menor del $20 \%$ en los valores brutos de absorbancia, por lo que se consideró que los ensayos realizados contaron con un nivel adecuado de repetibilidad $(23,24)$.

Estimación del valor de corte para la positividad de anticuerpos tipo IgG e IgM. La obtención del punto de corte para la positividad de anticuerpos tipo IgG e IgM se realizó con base en la desigualdad de Chebyshev (25), la cual establece que, cualquiera que sea la distribución probabilística de una variable aleatoria, no más de $\left(1 / k^{2}\right) \%$ de los valores de dicha distribución se encontrarán a más de $\mathrm{k}$ desviaciones estándar de la media. Para controlar la probabilidad de falsos positivos, se fijó en 0.0102 la probabilidad máxima tolerable, lo cual corresponde a punto de corte dado por el valor medio de las lecturas de los controles negativos más 7 desviaciones estándar. Usando este criterio los puntos de corte fueron 0.220 y 0.545 para IgG e IgM respectivamente.

Métodos estadísticos. El análisis de repetibilidad se basó en la evaluación de las dispersiones de los resultados de las DO obtenidas, mediante el CV, la desviación estándar (DE) y el error estándar (EE). Las gráficas de control de Levey Jennings fueron construidas a partir de los datos de DO utilizando el programa de Excel. Para el análisis de seropositividad de HEV en cerdos en las plantas de beneficio y según la subregión geográfica, se estimaron las frecuencias de los datos, los intervalos de confianza (con un nivel de confianza del $95 \%$ ) y las diferencias entre proporciones (con base en la prueba exacta de Fisher), con un nivel de confianza del $95 \%$; se consideran significativos valores de $p<0.05$. Todos los análisis fueron realizados usando las herramientas del programa GraphPad Prisma 5 (GraphPad Software, Inc. La Jolla, USA).

\section{RESULTADOS}

Repetibilidad y consistencia de las pruebas de ELISA indirecta modificadas para la detección de anticuerpos tipo IgG e IgM. Una vez determinada las diluciones óptimas de conjugado y de las muestras para el ensayo, se procedió a evaluar la repetibilidad de la prueba mediante la evaluación del CPP en seis 


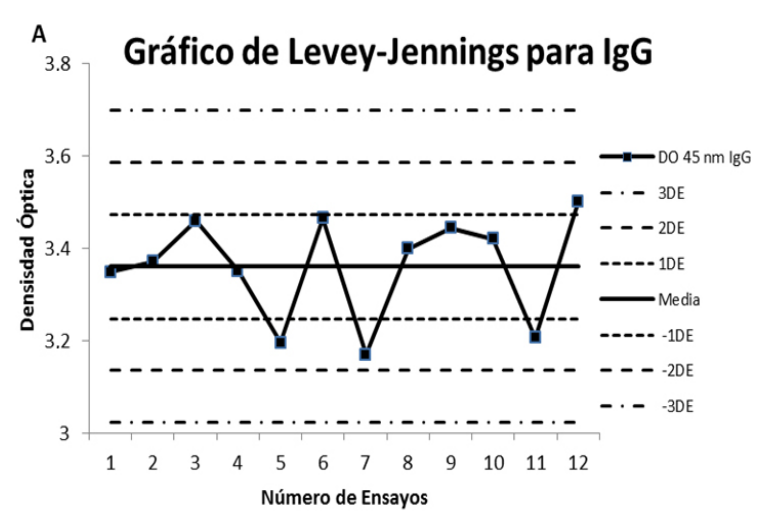

B Gráfico de Levey-Jennings para IgM

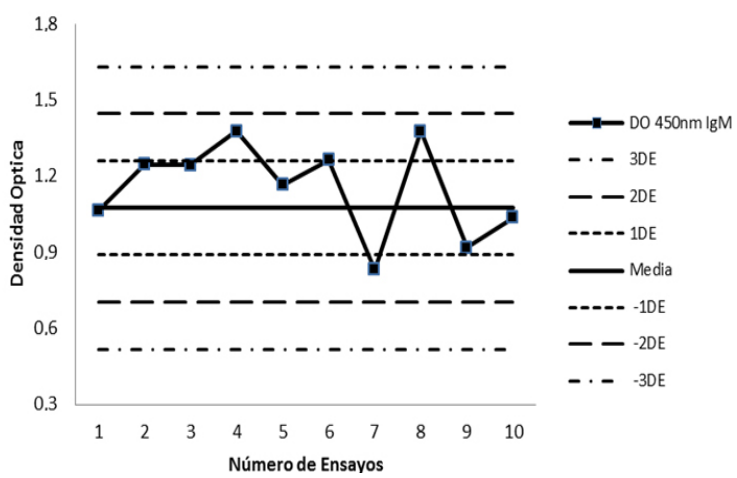

Figure 1. Control of the Variation of the $\mathrm{DO}_{450}$ de Positive Pig Control values (CPP). A: Levey-Jennings graphic for 12 determinations in different days for CPP for IgG. B; Levey-Jennings graphic for 10 determinations on different days for CPP for IgM. DE: Standard deviation.

by the manufacturer in each of the tests (data not shown).

Frequency of specific HEV antibodies in swine serum from Antioquia. The frequency of positivity found in the serum of pigs sampled in the slaughterhouses in Antioquia, with cut off points estimated in the study to detect IgG and IgM, was $100 \%$ and $82.06 \%$, respectively. ensayos independientes con dos operarios distintos. Los valores obtenidos del CV para el CPP fueron de $3.86 \%$ y $18.88 \%$ para IgG e IgM respectivamente (Tabla 1 ).

Los valores de $\mathrm{DO}_{450}$ de los CPP en cada uno de los montajes de las pruebas para los dos anticuerpos, fueron controlados a lo largo del estudio mediante gráficos de Levey-Jennings como lo muestra la figura 1 , los valores obtenidos en cada una de las determinaciones no excedieron el valor promedio en más de dos DE tanto para IgG como IgM. De igual manera se observó que todos los controles del kit funcionaron dentro de los parámetros definidos por el fabricante en cada una de las pruebas realizadas (datos no mostrados).

Frecuencia de anticuerpos específicos para HEV en suero de cerdos de Antioquia. La frecuencia de positividad encontrada en los sueros de los porcinos muestreados en las plantas de beneficio de Antioquia, con los puntos de corte estimados en el estudio para la detección de anticuerpos IgG e IgM fue de $100 \%$ y $82.06 \%$, respectivamente.

La positividad para IgM en cada planta de beneficio fueron similares y oscilaron entre 74.49 y $87.98 \%$ (Tabla 2), con una diferencia significativa entre la planta $A$ y las plantas $B$ y $E$ con valores $p=0.0067$ y $p=0.0042$ respectivamente. Al analizar la procedencia de los cerdos, se identificó que los animales muestreados provenían de seis de las nueve subregiones del departamento de Antioquia (Figura 2). Los porcentajes de cerdos positivos y los intervalos de confianza para la detección de anticuerpos IgM anti HEV según las subregiones de procedencia se muestran en la tabla 2 . El porcentaje de cerdos positivos para IgM fluctuó entre $77.78 \%$ para la subregión Occidente y $88.89 \%$ para la subregión Nordeste (Figura 2), pero no se encontró diferencia significativa entre las regiones analizadas.

Table 2. Percentage of positive pigs to detect IgM anti-HEV antibodies per plant and subregion.

\begin{tabular}{|c|c|c|c|c|c|c|c|}
\hline & \multicolumn{3}{|c|}{ Plant } & & \multicolumn{3}{|c|}{ Subregion } \\
\hline & $\mathbf{N}(+)$ & $\%$ & IC & & $N(+)$ & $\%$ & IC \\
\hline A & $183(161)$ & 87.98 & $92.31-82.37$ & Valle de Aburra & $165(132)$ & 80.00 & $85.81-73.08$ \\
\hline B & $98(73)$ & 74.49 & $82.76-64.69$ & North & $405(336)$ & 82.96 & $86.50-78.94$ \\
\hline C & $149(124)$ & 83.22 & $88.84-76.24$ & West & $54(42)$ & 77.78 & $87.96-64.40$ \\
\hline D & $188(159)$ & 84.57 & $89.42-78.60$ & Southeast & $84(71)$ & 84.52 & $91.49-74.99$ \\
\hline$E$ & $157(125)$ & 75.78 & $82.27-68.32$ & East & $49(39)$ & 79.59 & $89.76-65.66$ \\
\hline & & & & Northeast & $18(16)$ & 88.89 & $98.62-65.29$ \\
\hline Total & $775(636)$ & 82.06 & $84.70-79.18$ & Total & $775(636)$ & 82.06 & $84.70-79.18$ \\
\hline
\end{tabular}

$\mathrm{N}$ : Number of animals sampled. (+) Number of positive animals.

$95 \%$ IC: Intervals of confidence of $95 \%$ for the proportion of positive animals. 
IgM positivity in each slaughterhouse were similar and ranged between 74.49 and $87.98 \%$ (Table 2 ), with a significant difference between Plant $A$ and Plant $B$ and $E$ with values at $p=0.0067$ and $p=0.0042$, respectively. By analyzing the origin of the swine, it was seen that the sampled animals came from six of the nine subregions of the department of Antioquia (Figure 2). The percentages of positive pigs and confidence intervals for detecting IgM anti HEV antibodies by subregion of origin are shown in table 2 . The percentage of pigs positive for IgM ranged from $77.78 \%$ for the West subregion and $88.89 \%$ for the Northeast subregion (Figure 2), but no significant difference was found between the regions analyzed.

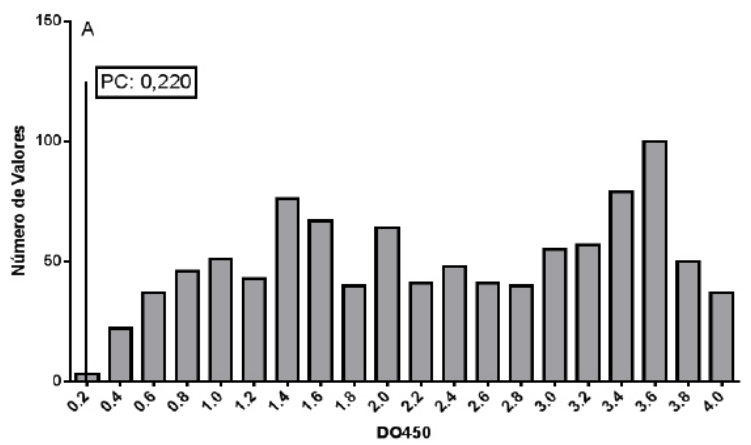

Figure 2: Distribution of frequencies of the $\mathrm{DO}_{450}$ to detect antibodies in sampled pigs. A: Distribution of 1000 samples of pig serum, evaluated for IgG, with the cut-off point (PC) at 0,220. B. Distribution of 775 samples of pig serum evaluated for IgM, with the cut-off point (PC) at 0.545 .

\section{DISCUSSION}

Many of the reported tests for the detection of anti HEV antibodies in pigs and other animals use modified commercial immunoassays to detect antibodies of the animal of interest $(8,16)$; however, there are few reports about the reliability of such modifications.

Evaluating the repeatability of a diagnostic test is one of the most important parameters to determine its reliability (23). The CV for the CPP for IgG and IgM obtained from the modifications to the commercial test, on different days and with different operators, were within the acceptable ranges for a diagnostic test (25); however, it is necessary in future studies to reaffirm the data obtained from the modified assay by evaluating the serum with a specific validated case for detecting antibodies in pigs and establishing the diagnostic sensitivity and specificity of the test.

\section{DISCUSIÓN}

Muchos de los ensayos reportados para la detección de anticuerpos anti HEV en cerdos y otros animales utilizan inmunoensayos comerciales modificados para la detección de anticuerpos del animal de interés $(8,16)$; sin embargo, son escasos los reportes acerca de la confiabilidad de dichas modificaciones.

La evaluación de repetibilidad de una prueba diagnóstica es uno de los parámetros más importantes para determinar la viabilidad de la misma (23). Los CV para los CPP para IgG e IgM obtenidos de las modificaciones del ensayo comercial, tanto en días diferentes, como con operarios distintos, estuvieron dentro de los rangos de aceptación para una prueba diagnóstica (25), sin embargo, es necesario en futuros estudios reafirmar los datos obtenidos del ensayo modificado mediante la evaluación de los sueros con un estuche específico y validado para la detección de anticuerpos en cerdos y establecer la sensibilidad y especificidad diagnóstica de la prueba.

Para cualquier ensayo serológico es fundamental la determinación del punto de corte, el cual se define como el nivel de actividad de anticuerpo que discierne el estatus positivo del negativo de un animal para un analito biológico particular (26). La forma más apropiada para calcularlo es utilizando sueros de referencia con estatus de infección conocido $(25,26)$. Ante la ausencia de sueros de referencia, frecuentemente se emplean estimaciones aproximadas mediante la evaluación de la distribución de frecuencias de la DO del anticuerpo que se desea detectar en una población numerosa o el empleo del promedio de los valores de DO de los controles negativas y sumándole varias DS (27).

En este estudio se obtuvo una distribución de frecuencias bimodal, en el caso de la detección de anticuerpos tipo IgG, por lo cual se hizo una primera aproximación al punto de corte usando una herramienta estadística de resolución de mezclas finitas $(8,24,26)$, (datos no mostrados).

A partir de aquí se pudo estimar un punto de corte en 3.31, que arrojó una seropositividad de $26 \%$ (datos no mostrados). Este valor podría sobreestimar la especificidad de la prueba, pues valores de $\mathrm{DO}_{450}$ por ejemplo de 1.6 se declararían como negativos, aumentando el riesgo de tener una proporción de falsos negativos. Por lo tanto, se determinaron los puntos de corte mediante un segundo enfoque que consistió en establecer el valor de corte 
For any serological test it is essential to determine the cutoff, which is defined as the level of activity of antibody that discerns the positive status of the negative of an animal for a particular biological analyte (26). The most appropriate way to calculate it is by using the reference serum of known status $(25,26)$. In the absence of reference serum, often rough estimates are used by evaluating the distribution frequencies of the OD of the antibody to be detected in a large population or using the average OD values of the negative controls are used and adding various DS (27).

In this study a distribution of bimodal frequencies was obtained in the case of detecting IgG antibodies, for which a first approach to the cutting point was made using a statistical tool to resolve finite mixtures $(8,24,26)$ (data not shown).

From that it was possible to estimate a cut-off point of 3.31, which yielded a seropositivity of $26 \%$ (data not shown). This value may overestimate the specificity of the test, since $\mathrm{DO}_{450}$ values, for example of 1.6 , would be declared negative, increasing the risk of having a proportion of false negatives. Therefore, the cutoff points were determined using a second approach that consisted of establishing the cut-off value based on the average values of $\mathrm{DO}_{450}$ of the negative controls plus 7 DS (27), decreasing the probability of false negatives, methodology which allows a more realistic approximation of the situation of virus positivity for pigs in this study.

In this context, the results shown indicated that all animals that arrived at slaughterhouses in Antioquia in the study period (the average slaughter age in Antioquia is 22 weeks (28)), were exposed to HEV at some point in the production process. Studies of natural infection in pigs show that these are infected at some point after the titers of maternal antibodies for IgG have decreased (between 8-10 weeks of life) approximately between week 14 to 17. Their IgG antibodies can be detected in a high proportion of pigs at slaughter age (29), which is consistent with that observed in this study.

Unlike IgG antibodies, IgM antibodies in naturally infected pigs decreased 4 to 7 weeks after infection, that is, between 15-17 weeks of age in a large amount of positive animals, but at slaughter age this ratio tends to decrease (29). The reason why in this study the proportion of pigs that are seropositive for IgM at slaughter age was high is unknown, but it could be related to the handling of animals in herds (density of animals on the premises, biosanitary management on farms, type of production, level of technology etc.) or greater pathogenicity of the virus circulating in the region. basado en los valores del promedio de las $\mathrm{DO}_{450}$ de las controles negativos más 7 DS (27), disminuyendo la probabilidad de falsos negativos, metodología que permite hacer una aproximación más realista de la situación de positividad para este virus en los cerdos del estudio.

En este contexto, los resultados mostrados indicaron que todos los animales que llegaron a beneficio en las plantas de faenado de Antioquia en el periodo de estudio (la edad promedio de sacrificio en Antioquia es de 22 semanas (28)), estuvieron expuestos al HEV en algún punto en el proceso de producción. Los estudios de infección natural en cerdos muestran que estos se infectan tiempo después de que han disminuido los títulos de anticuerpos maternales tipo IgG, (entre las semana 8-10 de vida) luego seroconvierten aproximadamente entre las semana 14 a 17. Los anticuerpos propios tipo IgG pueden ser detectados en una proporción alta de los cerdos en la edad de sacrificio (29), lo que coincide con lo observado en este estudio.

A diferencia de los anticuerpos tipo IgG, los anticuerpos tipo IgM en los cerdos infectados naturalmente disminuyen 4 a 7 semanas después de la infección, es decir que entre las semanas 15-17 de vida hay una gran proporción de animales positivos, pero en la edad de sacrificio esta proporción suele disminuir (29). La razón por la cual en este estudio la proporción de cerdos seropositivos para IgM en edad de beneficio fue alta se desconoce, sin embargo podría estar relacionada con el manejo de los animales en las piaras (densidad de animales en las instalaciones, manejo biosanitario en las granjas, tipo de producción, nivel de tecnificación etc.) o mayor patogenicidad del virus que circula en la región.

Adicional a esto, la positividad para anticuerpos tipo IgM, sugiere infección reciente y aunque la viremia y la periodo de excreción son relativamente cortos en los cerdos (17), cabe la posibilidad de que una proporción importante de animales que estuvieron excretando virus al ambiente al momento del faenado.

Las diferencias observadas en la positividad para IgM en las plantas de beneficio podrían estar relacionadas con el flujo de animales procedentes de las subregiones con mayor positividad, pues es poco probable que haya un aumento en la producción de IgM por la permanencia tan corta de los cerdos en cada planta antes del beneficio. 
In addition to this, the positivity for IgM antibodies suggests recent infection and although viremia and the excretion period are relatively short in pigs (17), it is possible that a significant proportion of animals that were the environment were excreting the virus at the time of slaughter.

The observed differences in positivity for IgM in slaughterhouses could be related to the flow of animals from the subregions with greater positivity, since it is unlikely to have increased in IgM production in the short stay at the slaughterhouse. HEV infection in pigs produced no apparent clinical signs or caused changes that were visible in the health inspections carried out in the slaughterhouse (29); however, given the high rates of positivity found, it is possible that the pigs may be have associated microscopic liver lesions.

Pork meat and in particular livers are major part of the diet in some sectors of the Colombian population. The high percentage of recent infection in pigs at slaughterhouses suggests that livers sold in Antioquia may be contaminated with the virus, so it is advisable to take care to consume them after an adequate cooking process, since it has been shown that the virus is inactivated at temperatures above $70^{\circ} \mathrm{C}$ held for 10 minutes (30).

The high seropositivity of IgG and IgM antibodies found in this study are greatly important to public animal health since it indicates that the virus is circulating on swine herds of department of Antioquia (and probably the country), and that a significant proportion of animals at slaughter age could be shedding the virus into the environment, which should draw the attention of the scientific community to study the dynamics of the virus in the country, and the health authorities to implement assessment and control measures to prevent the transmission of HEV to the swine production in the country.

In conclusion, as far as the research group knows, this is the first serologic evidence of the presence of HEV in pigs at slaughtering age in Colombia, and although the values of antibody seropositivity in the animals in the study was high, it is necessary to investigate individual conditions that contribute to pigs for human consumption in Antioquia being exposed to the virus and therefore generate control measures to prevent the spread of the virus in swine production in the department.
La infección por HEV en cerdos no produce signos clínicos aparentes, ni provoca cambios que sean visibles en las inspecciones sanitarias que se realizan en las líneas de beneficio (29); sin embargo, dados los altos porcentajes de positividad encontrados es posible que los cerdos puedan presentar lesiones hepáticas microscópicas asociadas.

La carne de cerdo y en particular los hígados hacen parte importante de la dieta en algunos sectores de la población colombiana. El alto porcentaje de infección reciente en los cerdos en las plantas de beneficio siguiere que los hígados comercializados en Antioquia podrían estar contaminados con el virus, por lo que es recomendable tomar la precaución de consumirlos tras un buen proceso de cocción, pues se ha demostrado que el virus se inactiva a temperaturas por encima de $70^{\circ} \mathrm{C}$, durante 10 minutos (30).

La alta seropositividad de los anticuerpos tipo IgG e IgM encontrados en este estudio son de gran importancia para la salud publica animal puesto que indican que el virus está circulando en buena parte de las producciones porcinas del departamento de Antioquia (y probablemente del país) y que una proporción considerable de los animales en edad de sacrificio podrían estar excretando virus al ambiente, lo cual debe llamar la atención de la comunidad científica para realizar estudios sobre la dinámica del virus en el país y a las autoridades sanitarias para implementar medidas de evaluación y control que permitan evitar la trasmisión del HEV entre las producciones porcinas del país.

En conclusión, para conocimiento del grupo de investigación, esta es la primera evidencia serológica de la presencia de HEV en cerdos en edad de beneficio en Colombia y aunque los valores de seropositividad de anticuerpos en los animales del estudio fue alta, se hace necesario investigar las condiciones particulares que están contribuyendo a que los cerdos para consumo humano en Antioquia estén expuestos al virus y de esta forma generar medidas de control que impidan la diseminación del virus en las producciones porcinas del departamento. 


\section{REFERENCIAS}

1. Aggarwal R, Naik S. Epidemiology of hepatitis E: current status. J Gastroenterol Hepatol 2009;24(9): 1484-93.

2. Meng $X J$. Zoonotic and foodborne transmission of hepatitis $E$ virus. Semin Liver Dis 2013;33(1):41-49.

3. Kumar S, Subhadra S, Singh B, Panda BK. Hepatitis E virus: the current scenario. Int J Infect Dis 2013; 17(4):e228-e233.

4. Kumar A, Beniwal M, Kar P, Sharma JB, Murthy NS. Hepatitis $E$ in pregnancy. Int J Gynaecol Obstet 2004;85(3):240-244.

5. Echevarría JM, González JE, Lewis-XimenezLL, Dos Santos DR, Munné MS, Pinto MA, et al.Hepatitis E virus infection in Latin America: a review. J Med Virol 2013; 85(6):1037-1045.

6. Vitral CL, Alves M, Lewis-Ximenez LL, Khudyakov YE, Lopes dos Santos DR, Gaspar AM. Serological evidence of hepatitis $E$ virus infection in different animal species from the Southeast of Brazil. Mem Inst Oswaldo Cruz 2005;100(2):117-122.

7. Cossaboom CM, Córdoba L, Cao D, Ni YY, Meng $\mathrm{XJ}$. Complete genome sequence of hepatitis $\mathrm{E}$ virus from rabbits in the United States. J Virol 2012; 86(23):13124-13125

8. Rutjes SA, Lodder-Verschoor F, Lodder WJ, van der Giessen J, Reesink H, Bouwknegt M, et al. Seroprevalence and molecular detection of hepatitis $E$ virus in wild boar and red deer in The Netherlands. J Virol Methods 2010; 168(12):197-206.

9. Pourpongporn $P$, Samransurp $K$, Rojanasang $P$, Wiwattanakul S, Srisurapanon S. The prevalence of anti-hepatitis $E$ in occupational risk groups. J Med Assoc Thai 2009; 92(Suppl 3):S38-S42

10. Ma H, Geng Y, Li Z, Harrison TJ, Huang W, Wang $Y$. Analysis of the complete genome sequences of one swine and two human hepatitis $E$ virus genotype 4 strains isolated in Beijing, China. Infect Genet Evol 2013; 18:42-47.

11. Wang H, He Y, Shen Q, Wang X, Yang S, Cui $L$, et al. Complete genome sequence of the genotype 4 hepatitis $E$ virus strain prevalent in swine in Jiangsu Province, China, reveals a close relationship with that from the human population in this area. J Virol 2012; 86(15):8334-8335.
12. Dong C, Meng J, Dai $X$, Liang JH, Feagins AR, Meng XJ, et al. Restricted enzooticity of hepatitis E virus genotypes 1 to 4 in the United States. J Clin Microbiol 2011; 49(12):4164-4172.

13. Garkavenko O, Obriadina A, Meng J, Anderson DA, Benard HJ, Schroeder BA, et al. Detection and characterisation of swine hepatitis $E$ virus in New Zealand. J Med Virol 2001; 65(3):525-529.

14. Cooper K, Huang FF, Batista L, Rayo CD, Bezanilla $J C$, Toth $T E$, et al. Identification of genotype 3 hepatitis E virus (HEV) in serum and fecal samples from pigs in Thailand and Mexico. $\mathrm{J}$ Clin Microbiol 2005; 43(4):1684-1688.

15. Seminati C, Mateu E, Peralta B, de Deus N, Martin $M$. Distribution of hepatitis $E$ virus infection and its prevalence in pigs on commercial farms in Spain. Vet J 2008 175(1):130-132.

16. Munné MS, Vladimirsky $S$, Otegui $L$, Castro $R$, Brajterman $L$, Soto $S$, et al. Identification of the first strain of swine hepatitis $E$ virus in South America and prevalence of anti-HEV antibodies in swine in Argentina. J Med Virol 2006; 78(12):1579-1583.

17. Paiva HH,Tzaneva V, Haddad R, Yokosawa J. Molecular characterization of swine hepatitis $\mathrm{E}$ virus from southeastern Brazil. Braz J Microbiol. 2007; 38(4):693-698.

18. Ibarra VH, Riedemann GS, Reinhardt VG, Calvo AM. Presence of anti hepatitis $E$ virus antibodies in swine: is it an animal reservoir for hepatitis. Rev Med Chil 2007; 135(8):997-1001.

19. Kase JA, Correa MT, Luna C,Sobsey MD.Isolation, detection and characterization of swine hepatitis $E$ virus from herds in Costa Rica. Int J Environ Health Res 2008;18(3):165-176.

20. Agronet.com [sede web] Bogotá: Departamento Administrativo Nacional de Estadística (DANE); 23 de octubre de 2012[Acceso 15 de diciembre de 2013] Boletín mensual INSUMOS Y FACTORES DE PRODUCCIÓN: La carne de cerdo en el mundo. URL Disponible en: http://www.agronet. gov.co

21. Huang FF, Haqshenas G, Guenette DK,Halbur PG, Schommer SK, Pierson FW, et al. Detection by reverse transcription-PCR and genetic characterization of field isolates of swine hepatitis $\mathrm{E}$ virus from pigs in different geographic regions of the United States. J Clin Microbiol 2002; 40(4):1326-1332. 
22. Leblanc $D$, Ward $P$, Gagné $M J$, Poitras $E$, Müller $P$, Trottier $Y L$, et al. Presence of hepatitis $E$ virus in a naturally infected swine herd from nursery to slaughter. Int J Food Microbiol 2007; 117(2):160-166.

23. Jacobson RH. Validation of serological assays for diagnosis of infectious diseases. Rev Sci Tech $1998 ; 17: 469-526$.

24. Chernick, MR. The Essentials of Biostatistics for Physicians, Nurses, and Clinicians. New Jersey. John Wiley \& Sons. 2011. pp.49-50.

25. OIE [sede web]. Manual of Diagnostic Tests and Vaccines for Terrestrial Animals 2013. Principles and methods of validation of diagnostic assays for infectious diseases. 2013 [Acceso 15 diciembre 2013] URL Disponible en: http://www. oie.int/fileadmin/Home/fr/Health_standards/ tahm/1.01.05_VALIDATION.pdf

26. Crowther JR. The ELISA guidebook. $2^{\text {nd }}$ Edition. New York; Human press: 2008.
27 Mizuo H, Suzuki K, Takikawa Y, Sugai Y, Tokita $\mathrm{H}$, Akahane $\mathrm{Y}$, et al.Polyphyletic strains of hepatitis $E$ virus are responsible for sporadic cases of acute hepatitis in Japan. J Clin Microbiol 2002;40(9):3209-3218.

28. Díaz CA, Rodríguez MN, Vera VJ, Ramirez G, Casas GA, Mogollón JD. Caracterización de los sistemas de producción porcina en las principales regiones porcícolas colombianas. Rev Colomb Cienc Pecu 2011; 24(2): 131-144.

29. de Deus N, Casas M, Peralta B,Nofrarías M, Pina S, Martín M,et al. Hepatitis E virus infection dynamics and organic distribution in naturally infected pigs in a farrow-to-finish farm. Vet Microbiol 2008; 13(1-2):19-28.

30. Yunoki $M$, Yamamoto $S$, Tanaka $H$, Nishigaki $H$, Tanaka Y, Nishida A, et al. Extent of hepatitis E virus elimination is affected by stabilizers present in plasma products and pore size of nanofilters. Vox Sang 2008; 95(2):94-100. 